\title{
THE STATUS OF VESICULAR ARBUSCULAR MYCORRHIZAL ASSOCIATIONS WITH MEDICINAL PLANTS IN MIHINTALE SANCTUARY
}

\author{
K.S.N. Silva* and P.N. Yapa \\ Department of Botany, Rajarata University, Sri Lanka \\ sujanisilva@yahoo.com*
}

\begin{abstract}
Sri Lanka has an enormous diversity of medicinal plants, and most are in dry zone forests. Mihintale sanctuary has some of the widely used medicinal plants in our ayurvedic system. Vesicular Arbuscular mycorrhiza (VAM) is the most abundant form of mycorrhiza and, plays a very important role in enhancing plant growth by increased nutrient uptake. This study investigates the presence of VAM colonization in several selected medicinal plants in disturbed and undisturbed sties in the Mihintale sanctuary. The results may be used to conserve those medicinal plants from destruction due to over exploitation. Root Samples were taken randomly from fourteen plant species in both disturbed and undisturbed sites in order to determine the effect of soil disturbance due to human activities on VAM colonization. Sub samples of fine roots of each species were quantified for VAM colonization by performing standard procedures. All the species had VAM colonization but was relatively higher with the plants in undisturbed site than in disturbed site. . Results indicate that the soil disturbances cause a decrease in VAM colonization in the study species.
\end{abstract}

Keywords: Vesicular Arbuscular Mycorrhiza, Medicinal Plants, Soil Disturbance, Conservation

\section{INTRODUCTION}

Medicinal plants have been an important resource for human health care from prehistoric times to the present day. About $35 \%$ of the Sri Lankan population is primarily dependent on ayurveda and traditional systems of health care, particularly in rural situations (Jayaweera, 1982). Medicinal plants are important for Pharmacological research and drug development, not only as plant constituents used directly as therapeutic agents, but also as starting materials for the synthesis of drugs or as models for pharmacologically active compounds (Milliken, 2000). They are increasingly becoming economically important in both developing and developed countries due to growing recognition of natural products, being non-toxic, having no side effects and easy availability at affordable prices (Radhika and Rodrigues, 2010).

There are over 655 medicinal plant species in Sri Lanka and about 208 are commonly used in the ayurvedic system (Jayaweera, 1982, Gunasena and Pushpakumara, 2004). Amonng those, 80 major medicinal plant species of Sri Lanka are now considered to be threatened (Abeywardana and Hettiaratchi, 2001). Majority of medicinal plants are found in the dry zone forests (REFF). Mihintale sanctuary has a high diversity of medicinal plants. Although termed as a protective site, medicinal plants in the sanctuary are threatened by over exploitation, habitat destruction through shifting cultivation, cutting down trees for timber, over grazing by domestic cattle herds etc. (REFF) Therefore, steps must be taken to protect medicinal plants within the sanctuary.

The symbiotic association between fungi and the roots of higher plants is called mycorrhiza. Of the different types, arbuscular mycorrhizae (AM) are ubiquitous in their distribution and occur abundantly (Gabor, 1991; Miller, 1995). They are organisms that form an interface between soils and plant roots, and are sensitive to changes in soil and plant conditions. They are known to improve the plant growth through, better uptake of nutrients such as $\mathrm{P}, \mathrm{Zn}, \mathrm{Cu}$, $\mathrm{Ca}, \mathrm{K}, \mathrm{Br}, \mathrm{Cr}$ (Lambert, et al.,1979; Brundrett, 2009) and water, resistance to drought and 
increased resistance to root pathogens. They also improve the activity of $\mathrm{N}$ fixing organisms in the root zone (Brundrett, 2009).

Though there are reports on beneficial effects of VAM on other crops, only a few reports on the VAM association with medicinal plants. The purpose of this study was to investigate the extent of VAM association in some selected medicinal plants in the Mihintale sanctuary and determine the effect of soil disturbance on VAM colonization in the selected medicinal plants. Since an increase in dry weight has been observed in plants inoculated with VAM in earlier studies (Gabor, 1991), the results of this study will be used to determine which medicinal plants can easily be cultivated within and outside the sanctuary, as a means of conservation, at lower expenses by using VAM.

\section{MATERIALS AND METHODS}

\subsection{SITE OF COLLECTION}

The site chosen for medicinal plant root collection was the Mihintale sanctuary, in which a disturbed and an undisturbed sites were selected.

\subsection{COLLECTION OF ROOT SAMPLES}

Root Samples were taken randomly from fourteen plant species in both disturbed and undisturbed sites in the Mihintale sanctuary. Those were Justica adhathoda, Cassia fistula, Elephantopus scaber, Jasminum sambac, Asparagus racemosus, Desmodium triflorum, Hemidesmus indicus, Solanum xanthocarpum, Azadiractha indica, Terminalia arjuna, Clitoria ternatea, Aerva lanata, Cassia auriculata and Diospyros malabarica. Sub samples of fine roots of each medicinal plant species were thoroughly washed in running tap water and rootlets were selected and cut into $1 \mathrm{~cm}$ segments and fixed in formaldehyde acetic acid solution (FAA).

\subsection{QUANTIFICATION OF VESICULAR ARBUSCLAR MYCORRHIZAL INFECTION}

Root pieces were washed thoroughly to remove FAA and were cleared by boiling with $10 \%$ $\mathrm{KOH}$ at $96-98^{\circ} \mathrm{C}$. Then Roots were washed in distilled water, and acidified with $1 \mathrm{M} \mathrm{HCl}$ for 20 minutes and were stained in $0.05 \%$ trypan blue, in a water bath at $75^{\circ} \mathrm{C}$. The excess stain was removed by washing with distilled water, in a water bath at $75^{\circ} \mathrm{C}$ (Brundrett et al., 1984). Stained roots were kept stored in acetic acid for preparation of slides. Slides were prepared by placing thirty root segments each mounted on slides with glycerin. These were microscopically examined for colonization by determining the percentage root segments containing number of arbuscules, vesicles, and aseptate hyphae using the modified grid transect method (McGonigle et al., 1990). A statistical analysis was carried out to determine the significance of difference in distribution of VAM among the medicinal plants in disturbed and undisturbed sites.

\section{RESULTS AND DISCUSSION}

All the medicinal plants showed mycorrhizal colonization and there was wide variation in percentage root colonization among species. Plants in the undisturbed site had higher AM colonizartion than those in the disturbed site (Table 1). Percentage colonization ranged from $89.74 \%$ (Asparagus racemosus in the undisturbed site) to $4.10 \%$ (Justica adhathoda in the disturbed site). However, in four species (Cassia fistula, Terminalia arjuna, Aerva lanata, Diospyros malabarica; Table 1) mycorrhizal colonization could not be quantified due to highly pigmentation of their roots. As a result, the procedure carried out to clear the roots, had not worked properly. . 
In The percentage of AM colonization among medicinal plants between the two sites was insignificant and do not support the hypothesis. This may be because Mihintale sanctuary, as a whole is quite disturbed compared to a virgin forest and the undisturbed site was only relative to the disturbed site in the sanctuary. The results revealed that VAM fungal colonization decreases with increasing disturbance and destruction of soil (Figure 1). About $80 \%$ of locally supplied medicinal plants were collected from the wild. The rise in population may be the reason for over exploitation of forest resources, leading to forest degradation and soil disturbance.

Plant cover loss influences AMF propagules activity and availability (Brundrett and Abbott, 1994) leading to a significant decrease in spores diversity, in the amount of viable mycelium and in colonization, as well as a loss in infectivity (Allen et al,. 1998; Hart and Reader, 2004). The loss of plant cover leads to erosion, especially during rainy seasons, most fungal spores near the soil surface in the rhizosphere can be directly eroded away (REFF). These explain why the mycorrhizal colonization of medicinal plants in disturbed site is less than those of the undisturbed site.

The medicinal plants used for the study possessed vesicular arbuscular mycorrhizal associations and thus, they can be used for cultivation within the sanctuary using VAM fungal inoculants to increase the number of these plants. This would safeguard their existence within the sanctuary. Since VAM fungi contribute to plant growth and survival by reducing stresses and enhancing nutrient uptake, heavy fertilization would not be necessary. Mycorrhiza itself acts as an environment friendly bio fertilizer (REFF). This would help to cut down the cost of fertilization in reforestation projects in Mihintale sanctuary as well as in any other locations. By integrating medicinal plant cultivation using VAM fungal inoculants into farming systems, it will be possible to meet the demand for medicinal plants of the villagers while minimizing exploitation of plants in the sanctuary.

Various sorts of land uses, such as mining or overgrazing, degrade soil. Mycorrhizal filaments produce humic compounds and organic "glues" (extracellular polysaccharides) that bind soils into aggregates and improve soil porosity and structure positively (REFF). This allows root growth and distribution, water and nutrients movement into the plants (Burns and Davies, 1986). Thus, by having VAM increase soil fertility. Therefore, $t$ medicinal plants in association with VAM fungi can be used for regeneration of degraded lands. Researchers are beginning to suggest that degraded areas should be inoculated before or upon planting (Hall and Armstrong, 1979). 
Table 1: Presence and the extent of root colonization by VAM in medicinal plants

\begin{tabular}{|c|c|c|c|c|c|c|c|c|c|c|}
\hline \multirow{3}{*}{ Common name } & \multirow{3}{*}{ Botanical name } & \multirow{3}{*}{ Family } & \multicolumn{8}{|c|}{ Mycorrhizal colonization } \\
\hline & & & \multicolumn{4}{|c|}{$\mathrm{D}$} & \multicolumn{4}{|c|}{ UD } \\
\hline & & & $\mathrm{V}$ & A & $\mathrm{H}$ & $\mathrm{C} \%$ & $\mathrm{~V}$ & A & $\mathrm{H}$ & $\mathrm{C} \%$ \\
\hline Adathoda & Justica adhathoda & Acanthaceae & + & + & + & 4.10 & + & + & + & 17.06 \\
\hline *Ehala & Cassia fistula & Fabaceae & + & + & + & - & + & + & + & - \\
\hline Ethadi & Elephantopus scaber & Asteraceae & + & + & + & 5.01 & + & + & + & 86.25 \\
\hline Gatapichcha & Jasminum sambac & Oleaceae & + & + & + & 11.33 & + & + & + & 14.66 \\
\hline Hathawariya & Asparagus racemosus & Liliaceae & + & + & + & 80.00 & + & + & + & 89.74 \\
\hline Heenundupiyaliya & Desmodium triflorum & Fabaceae & + & + & + & 12.34 & + & + & + & 14.70 \\
\hline Iramusu & Hemidesmus indicus & Asclepiadaceae & + & + & + & 4.50 & + & + & + & 10.52 \\
\hline Katuelbatu & Solanum xanthocarpum & Solanaceae & + & + & + & 6.25 & + & + & + & 7.89 \\
\hline Kohomba & Azadirachta indica & Meliaceae & + & + & + & 18.82 & + & + & + & 24.29 \\
\hline *Kumbuk & Terminalia arjuna & Combretaceae & + & + & + & - & + & + & + & - \\
\hline Nilkatarolu & Clitoria ternatea & Fabaceae & + & + & + & 11.83 & + & + & + & 59.92 \\
\hline *Polpala & Aerva lanata & Amaranthaceae & + & + & + & - & + & + & + & - \\
\hline Ranawara & Cassia auriculata & Fabaceae & + & + & + & 18.75 & + & + & + & 35.04 \\
\hline *Thimbiri & Diospyros malabarica & Ebenaceae & + & + & + & - & + & + & + & - \\
\hline
\end{tabular}

D - Disturbed site UD - Undisturbed site V - Vesicles

A - Arbuscules H - Aseptate hyphae

C\% - Percentage colonization of roots by Vesicular Arbuscular Mycorrhizae

* - Plants with highly pigmented roots in which percentage colonization could not be determined 


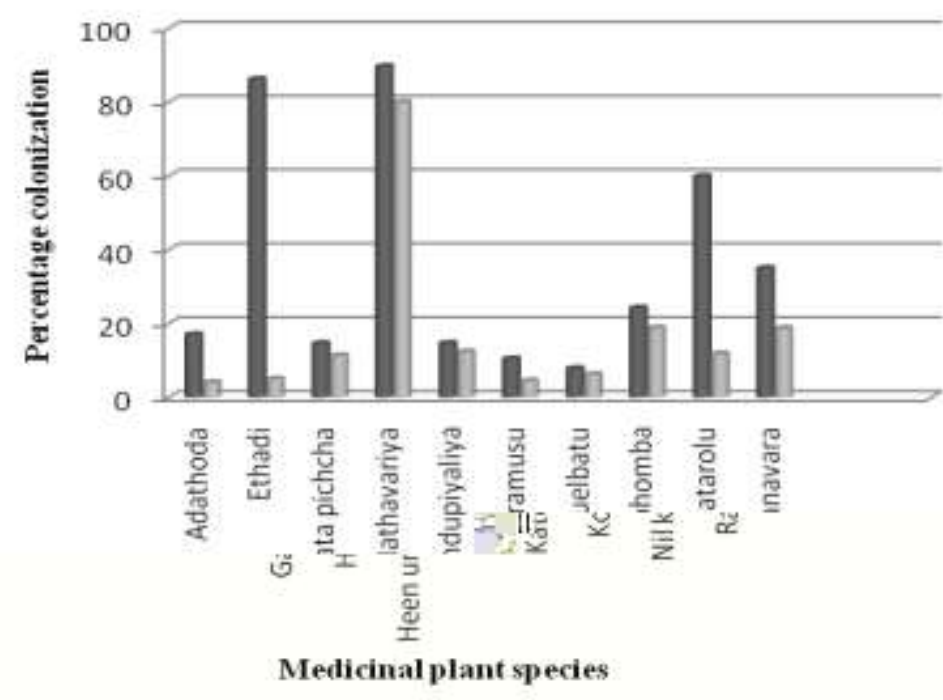

- Undisturbed site $(\%)$

= Disturbed site $(\%)$

Figure 1: Mycorrhizal colonization of medicinal plants in disturbed and undisturbed sites in Mihintale sanctuary

\section{CONCLUSIONS}

All the studied plant species had Vesicular arbuscular mycorrhizal associations. Inoculation of VAM during an early stage of acclimatization process of medicinal plants has become an alternative strategy for better establishment by improving the plant growth. Therefore, these plants can be grown with minimal expenses using VAM inoculants within the sanctuary as a means of protecting and conserving them.

VAM fungi are negatively affected by soil disturbance and thus show a decrease in percentage colonization in the medicinal plants of the disturbed sites in the sanctuary. Therefore, the composition of VAM community in an ecosystem will be an important determinant of plant response to soil disturbance.

Since VAM fungi increases soil fertility, they can be used for regeneration of degraded lands. Using medicinal plants with VAM associations for such projects allow conservation, meet demands of traditional ayurvedic practices in revelation of lands. Proper conservation measures regarding the Mihintale sanctuary must be followed in order to prevent disruption of land and valuable plants by people so that the VAM fungi network will remain unharmed, ensuring survival of medicinal plants as well as other plants.

\section{REFERENCES}

Abeywardana, N., Hettiaratchi, L.J.K., 2001. Statistics on the national demand for medicinal plants. Report No. MPP/R/21. IUCN Sri Lanka, Colombo.

Allen, E.B., Rincón, E. Allen, M.F., Pérez-Jiménez, A., Huante, P., 1998. Disturbance and seasonal dynamics of mycorrhizae in a tropical deciduous forest in Mexico. Biotropica 30, 261-274.

Brundrett, M.C., 2009. Mycorrhizal associations and other means of nutrition of vascular plants: understanding the global diversity of host plants by resolving conflicting information and developing reliable means of diagnosis. Plant Soil 320, 37-77. 
Brundrett, M.C., Abbott, L.K.., 1994. Mycorrhizal fungal propagules in the Jarrah forest. I. Seasonal study of inoculum levels. New Phytol. 127, 539-546.

Brundrett, M.C., Piche, Y., Peterson, R.L. (1984). A new method for observing the morphology of vesicular - arbuscular mycorrhizae. Can. J. of Bot. 62, 2128-2134.

Burns, R.G., Davies, J.A., 1986. The microbiology of soil structure. Biol. Agric. Hortic. 3, 95-113. Gabor, J., 1991. Mycorrhizae and crop productivity. In: Mycorrhizae in sustainable agriculture American Society of Agriculture Madison, Wisconson, USA, 1-29.

Hall, I.R., Armstrong, P., 1979. Effect of vesicular-arbuscular mycorrhizas on growth of white clover, lotus, and ryegrass in some eroded soils. New Zealand J.Agric. Res. 22, 479-484.

Jayaweera, D.M.A., 1982. Medicinal plants (indigenous and exotic) used in Ceylon, Parts 1-5. National Science Council of Sri Lanka, Colombo.

Lambert, D.H, Baker, D.E., Cole, H. J., 1979. The role of mycorrhizae in the interactions of phosphorus with zinc, copper and other elements. Soil Sci. Soc. Am. J. 43, 976-98.

McGonigle, T. P., Miller, M. H., Evans, D.G., Fairchild, G.L., Swan, J.A. (1990). A new method which gives an objective measure of colonization of roots by vesicular arbuscular mycorrhizal fungi. New Phyto. 115, 495-501.

Miller, M.H., McGonigle, T.P., Addy, H.D., 1995. Functional ecology of vesicular arbuscular mycorrhizas as influenced by phosphate fertilization and tillage in an agricultural ecosystem. Crit. Rev. Biotech. 15, 241-255.

Milliken, W., 2000. Sri Lanka conservation and sustainable use of medicinal plants project: operational support -Ethnobotany. Report No. MPP/R/10. IUCN Sri Lanka, Colombo.

Radhika, K.P., Rodrigues, B.F., 2010. Arbuscular mycorrhizal fungal diversity in some commonly occurring medicinal plants of Western Ghats, Goa region. J, Forest. Res. 21, 45-52. 